UDC 378.046-021.68:51

DOI https://doi.org/10.31470/2415-3729-2021-13-110-124

\title{
Methods of Formation of the Students-Mathematicians' Readyness to Study Mathematical Disciplines
}

\section{Oksana Zhernovnykova}

Doctor of Pedagogical Science (DSc), Professor,

Head of the Department of Mathematics,

H.S. Skovoroda Kharkiv National Pedagogical University,

$\triangle$ 29, Alchevskykh Str, Kharkiv, Ukraine, 61002

E-mail: oazhernovnykova@gmail.com

ORCID: http://orcid.org/0000-0002-5383-4493

\section{Yuliia Prostakova,}

Doctor of Philosophy in Pedagogy (Ph.D),

Associate Professor of the Department of Mathematics,

H.S. Skovoroda Kharkiv National Pedagogical University,

$\triangle 2$, Valentynivska Str., Kharkiv, Ukraine, 61022

E-mail: uss1905@ukr.net,

ORCID: https://orcid.org 0000-0002-8955-2818

Date of receipt of the article: April 18, 2021

Article accepted for publication: June 02, 2021

Методика формування готовності студентів-математиків до вивчення математичних дисциплін

\section{Оксана Анатоліївна Жерновникова}

доктор педагогічних наук, професор, завідувач кафедри математики

Харківський національний педагогічний університет імені Г. С. Сковороди,

$\bowtie$ вул. Валентинівська 2, Харків, Україна

\section{Юлія Сергіївна Простакова}

кандидат педагогічних наук, доцент кафедри математики, 
Харківський національний педагогічний університет імені Г.С. Сковороди

$\triangle$ вул. Валентинівська 2, Харків, Україна

Дата надходження статті: 18 квітня 2021 p. Стаття прийнята до друку: 02 червня 2021 р.

\section{Absract}

The introduction to the article analyzes the current state of formation of the students-mathematicians' readiness to study mathematical disciplines. The purpose of the study is to develop and scientifically substantiate the method of forming the studentsmathematicians' readiness to study mathematical disciplines. Methods. In the process of achieving the goal, the theoretical and practical methods of data retrieval and processing were applied. The results. The analysis of the researched problem gave an opportunity to characterize the essence of the concept «students-mathematicians' readiness to study mathematical disciplines». The students-mathematicians' readiness to study mathematical disciplines was defined as the result of mathematical training of a prospective university student, that is a necessary condition for forming the mathematical competence of graduates of pedagogical universities. The article defines the content of structural components of the formation of the students-mathematicians' readiness to study mathematical disciplines: motivational-value (presence of motives and needs in studying mathematics, awareness of the mathematical knowledge value for future professional activity), semantic (mathematical knowledge of school mathematics required to master basic mathematics knowledge of generalized methods of solving typical professional problems), instrumental (universal actions of generalized methods of solving typical professional problems that require the mathematical knowledge use), personal (communicative, creative abilities and personal qualities needed to solve typical professional problems). The didactic principles of forming the studentsmathematicians' readiness to study mathematical disciplines are the principles of cooperation, of professional orientation, fundamentality, modularity of the mathematical training content. Conclusions. The methods of formation of the students-mathematicians' readiness to study mathematical disciplines which contains interrelation of 
target, methodological, substantial, procedural and result-estimating components is developed. The prospects for further research are planned in the direction of the developed methodology implementation into the educational process of pedagogical universities for studentsmathematicians.

Key words: students-mathematicians, educational process, mathematical disciplines, university, readiness, formation.

\section{References}

1. Zhernovnykova, O. A. (2016). Metodolohichni pidkhody yak pidgruntia dydaktychnoi pidhotovky maibutnoho vchytelia matematyky do proektuvannia navchalnoi diialnosti starshoklasnykiv [Methodological approaches as a basis for didactic training of future mathematics teachers to design educational activities of high school students]. Pedagogical almanac, 29, 123-129 [in Ukraine].

2. Zhernovnykova, O. A., $\quad$ Peretiaha, L. Y., $\quad$ Kovtun, A. V., Korduban, M. V., Nalyvaiko, O. O., \& Nalyvaiko, N. A. (2020). The Technology of Prospective Teachers' Digital Competence Formation by Means of Gamification. Information Technologies and Learning Tools, 75(1), 170-185. https://doi.org/10.33407/itlt.v75i1.3036 [in Ukraine].

3. Zhernovnykova, O. A. (2016) Vybrani pytannia vykladannia matematyky $\mathrm{v}$ navchalnykh zakladakh serednoi profesiinoi ta zahalnoi osvity [Selected issues of teaching mathematics in secondary vocational and general education]: navch.-metod. posib. Kharkiv: Mitra [in Ukraine].

4. Zhernovnykova, O. A. (2015). Dydaktychna pidhotovka maibutnikh uchyteliv matematyky do proektuvannia navchalnoi diialnosti starshoklasnykiv: teoretychnyi ta metodychnyi aspekty [Didactic preparation of future teachers of mathematics for designing of educational activity of senior pupils: theoretical and methodical aspects]. Kharkiv : Vydavets Ivanchenko I.S. [in Ukraine]

5. Zhernovnykova, O. A. \&Proskurnia, O. I. (2020). Metodychni aspekty prohramy pidvyshchennia kvalifikatsii vchyteliv matematyky [Methodical aspects of the program of advanced training of mathematics teachers]. Adult education: world trends, Ukrainian realities and prospects: monograph. Kyiv, Kharkiv : Instytut osvity doroslykh imeni I. Ziaziuna NAPN Ukrainy, Kharkivskyi natsionalnyi pedahohichnyi universytet imeni H.S. Skovorody [in Ukraine]. 
6. Zhernovnykova, O. A., Shtefan, L. A., Fazan, V. V. (2017). Formuvannia hotovnosti maibutnikh uchyteliv matematyky do navchalnoho proektuvannia [Forming future mathematics teachers' instructional design skills]. Science and education, 10, 74-81. DOI: https://doi.org/10.24195/2414-4665-2017-10-9.

7. Nalyvaiko, O. (2019). Stop motion proekty yak zasib formuvannia tsyfrovoi kompetentnosti zdobuvacha osvity [Stop motion projects as a means of the formation students digital competence]. Scientific Notes of the Pedagogical Department, 1(45), 13-20. https:// doi.org/10.26565/2074-8167-2019-45-02 [in Ukraine].

8. Ponomarova, N. O., Olefirenko, N. V., Zhernovnykova, O. A. \& Masych, V. V. (2019). Potentsiini mozhlyvosti pozaaudytornoi roboty dlia intelektualnoho rozvytku maibutnikh uchyteliv fizyko-matematychnoho fakultetu Kharkivskoho natsionalnoho pedahohichnoho universytetu imeni H. S. Skovorody [Potential opportunities for extracurricular activities for the intellectual development of future teachers of the Faculty of Physics and Mathematics of Kharkiv National Pedagogical University named after G.S. Skovoroda]. Spiritual and intellectual education and training of young people in the XXI century: an international collective monograph. Kharkiv: Vyd. VNNOT [in Ukraine].

9. Shevchuk, L. D. (2019). Neperervna profesiina pidhotovka maibutnikh uchyteliv matematyky zasobamy IKT: teoretychni ta metodychni zasady [Continuous professional training of future teachers of mathematics by means of ICT: theoretical and methodical bases]: monograph. Kyiv : OLDI-PLIuS [in Ukraine].

10. Shevchuk, L. D. (2015). Profesiina pidhotovka maibutnoho vchytelia matematyky u protsesi navchannia u VNZ [Professional training of future mathematics teachers in the learning process]. Native school, 11-12, 44-47 [in Ukraine].

11. Grineva, V., Zhernovnykova, O. \& Kovalenko, O. (2018) European experience in training prospective teachechers. Leader. Elite. Society, 1, 91-99. doi: [in Ukraine]10.20998/2616-3241.2018.1.09.
12. Ponomarova, N.,
Gulich, O.,
Zhernovnykova, O., Olefirenko, N. \& Masych, N. (2021). Conditions of blended learning implementation in H. S. Skovoroda Kharkiv National Pedagogical University: experience of Physics and Mathematics Faculty. Second 
International Conference on History, Theory and Methodology of Learning (ICHTML 2021), May 12-14, 1-8.

13. Zolotukhina, S., Bashkir, O. \& Zhernovnykova, O. (2018). Stages of Training Future Mathematics Teachers in the Field of Pedagogical Improvisation. Science and education, 4, 80-86.

\section{Вступ}

Рівень інноваційного розвитку усіх галузей економіки України безпосередньо залежить від якості підготовки фахівців у вищій школі. Складовою професійної підготовки здобувача освіти $\epsilon$ вивчення математики, що застосовується майже у всіх наукових та виробничих галузях, оскільки без математичних розрахунків неможливе проєктування та створення життєво важливих для людини технічних об'єктів, продуктів, технологій, розв'язання економічних та фундаментальних науково-дослідних завдань природничих наук, моделювання космічних об'єктів та їх властивостей, природних явищ, вирішення побутових проблем, а розвиток логічного, абстрактного мислення, обумовлене вивченням математики, необхідно представникам гуманітарної галузі діяльності.

У затвердженій Концепції Нової української школи (2016) також наголошується на значущості математичної освіти. Важливою складовою професійною компетентності майбутніх фахівців $€$ математична компетентність, під якою розуміється здатність та готовність до застосування фундаментальних математичних знань та методів при вирішенні професійних завдань

Формування математичної компетентності у студентів здійснюється у процесі вивчення математичних дисциплін: математичного аналізу, аналітичної геометрії, алгебри та теорії чисел, теорії ймовірностей та інших. Багаторічна практика викладання математичних дисциплін в ЗВО надає підстави стверджувати, що студенти відчувають труднощі в їх опануванні, які виявляються в академічній успішності першокурсників. Дослідники обгрунтовано визначають такі причини даної проблеми: першокурсники не усвідомлюють значущості математичної підготовки в ЗВО для майбутньої професійної діяльності, що призводить до незначної навчальної мотивації (Жерновникова, 2016; Пономарьова, 2019; Шевчук, 2019); розрив між вимогами ЗВО до рівня ма- 
тематичних знань абітурієнтів та фактичним рівнем математичної підготовки випускників шкіл як порушення наступності в навчанні математики (Жерновникова, Перетяга, Ковтун, Кордубан, Наливайко, 2020); першокурсники мають розрізнені знаннями шкільного курсу математики, володіють конкретними прийомами рішення типових завдань, але не здатні до їх систематизації, узагальнення та раціонального використання у процесі вивчення математики у 3ВО (Grineva, Zhernovnykova, Kovalenko, 2018); психологічні труднощі першокурсників з запам'ятовуванням, розумінням, наочним поданням навчального матеріалу, що суттєво впливає на навчання студентів математики (Zolotukhina, Bashkir, Zhernovnykova, 2018).

Установлено, що до найбільш суттєвих причин, які не дозволяють студентам-першокурсникам успішно вивчати математичні дисципліни у ЗВО можна віднести: відсутність належної навчальної мотивації до вивчення математики; недостатній рівень знань шкільного курсу математики; несформованість універсальних навчальних дій, що використовуються під час вирішення математичних завдань; недостатньо розвинені комунікативні та творчі здібності, необхідні для колективної діяльності щодо реалізації навчальних проєктів.

Мета статті - розробити та науково обгрунтувати методику формування готовності студентів-математиків до вивчення математичних дисциплін.

\section{Матеріал і методи дослідження}

Серед використаних методів дослідження визначальними були такі: аналіз та узагальнення науково-методичних джерел задля теоретичного обгрунтування висвітлюваної проблеми, моделювання, синтез отриманих даних. Статистичні методи використовувалися на всіх етапах педагогічного експерименту: при загальній оцінці сформованості готовності студентів-математиків до вивчення математичних дисциплін.

\section{Результати та їх обговорення}

Численні та вагомі за теоретичними і практичними результатами напрацювання дослідників надають підстави стверджувати, що через несформованість системи базових математичних знань, недостатню математичну культуру та нерозвинену здатність до 
пізнавальної діяльності абітурієнтів, виникають бар'єри для вивчення математичної освіти у вищій школі (Ponomarova, Gulich, Zhernovnykova, Olefirenko, Masych, 2021). Підтвердженням сказаного є й те, що 2020-2021 навчальний рік в Україні оголошено Роком математичної освіти (указ президента України № 31/2020).

На думку вчених, труднощі, які зазнають студенти першого курсу при вивченні математики, природним чином знижують академічну успішність, погіршують якість математичної підготовки (Шевчук, 2015; Жерновникова, Штефан, Фазан, 2017). О. Жерновникова (2015) підкреслює, що труднощі із запам'ятовуванням, розумінням, наочним уявленням суттєво впливають на навчання математики студентів. Дослідниця виділяє два взаємопов'язаних компоненти труднощів: когнітивні здібності та мотиваційноособистісні особливості. Когнітивний компонент містить здібності загальнонавчального та спеціально-математичного характеру: концентрація уваги, образна пам’ять, словесна пам'ять, аналіз смислових зв'язків, класифікація, узагальнення, а також логічні, вербальні, просторові здібності. Мотиваційно-особистісні особливості, на думку вченої, обумовлені мотивацією у набутті знань, оволодінні професією, здобутті диплома, а також такими особистісними характеристиками, як емоційна стійкість, саморегуляція, впевненість у собі.

Незважаючи на достатню кількість науково-методичних досліджень, присвячених проблемі підготовки випускників шкіл до навчання математики у ЗВО (Жерновникова, Проскурня, 2020; Наливайко, 2018; Шевчук, 2018) педагогічна практика та результати констатувального етапу педагогічного експерименту показують, що першокурсники не готові до вивчення математики у ЗВО належним чином. Це призводить згодом до зниження рівня математичної компетентності випускників 3ВО.

Саме тому $3 \mathrm{BO}$ змушені самостійно вирішувати проблему формування готовності першокурсників до вивчення математичних дисциплін упродовж першого року навчання, оскільки вивчення цих дисциплін передбачено навчальними планами, як правило, на першому-другому курсах (Жерновникова, 2016).

Отже, психолого-педагогічні дослідження доводять, що готовність доцільно розглядати як складну структуровану систему 
взаємопов'язаних компонентів, сформованість яких необхідна для високого рівня готовності.

Погодимося 3 авторами досліджень (Ponomarova, Gulich, Zhernovnykova, Olefirenko, Masych, 2021), що структура готовності до вивчення математики у $3 \mathrm{BO} \epsilon$ цілісною системою взаємопов'язаних компонентів. Аналіз досліджень показав, що більшість авторів у структуру готовності до навчальної діяльності включають компонент, що характеризує сформованість мотиваційної складової у навчанні, оскільки спонукальним стимулом у навчальній діяльності виступає навчальна мотивація, яка має важливе значення для успішного навчання.

Проведений нами констатувальний етап педагогічного експерименту дозволив виявити суттєву недооцінку першокурсниками ролі математики у їхній майбутній професійної діяльності, що призводить до недостатньої навчальної мотивації щодо.

Усвідомлений прояв активності студентів у процесі вивчення математики у ЗВО визначає наявність потреби у навчанні, забезпечуючи, на наш погляд, мотиваційно-ціннісне сприйняття навчання.

На цій підставі, вважаємо за необхідне включити в структуру готовності до вивчення математики у ЗВО студентами першого курсу мотиваційно-ціннісний компонент, який має містити мотиви та потреби вивчення математики, усвідомлення цінності математичних знань для майбутньої професійної діяльності, тобто, прагнення мати сформовану математичну компетентність.

Як інший необхідний компонент готовності студентів першого курсу до вивчення математики у ЗВО визначимо математичні знання, на основі яких студенти опановуватимуть математичні дисципліни. Назвемо цей компонент змістовним.

У наукових дослідженнях вчених зазначається (Zolotukhina, Bashkir, Zhernovnykova, 2018), що знання людині необхідні, як знаряддя праці, за допомогою якого вона має навчитися діяти. Справді, для успішного вирішення професійних завдань, які потребують математичних знань, сучасному фахівцю доцільно опанувати узагальненими методами їх вирішення, реалізація яких потребує оволодіння математичними знаннями.

Цими знаннями студенти опановують у процесі опанування освітньої програми «014 Середня освіта (Математика)». Тому для 
визначення змістовного компонента готовності першокурсників до вивчення математики необхідно:

- провести аналіз змісту робочих навчальних програм базових математичних дисциплін, з метою визначення інваріантного змісту математичних знань та методів, до вивчення яких мають бути готові першокурсники;

- виявити теми шкільного курсу математики, необхідні для освоєння інваріантного змісту.

Упроцесіматематичноїпідготовкиупедагогічномууніверситеті студенти мають опанувати узагальнені методи вирішення задач, тому до структурного складу готовності першокурсників щодо вивчення математики вважаємо за необхідне включити компонент, в основу якого будуть покладені узагальнені дії даних методів. Визначимо цей компонент як інструментальний. 3 цією метою необхідно: проаналізувати науково-педагогічні дослідження, присвячені виявленню типів професійних завдань фахівців різних напрямків, з метою аналізу типології професійних завдань; виявити перелік узагальнених дій, що входять до складу більшості узагальнених методів вирішення задач, тобто, є універсальними; включити виявлені узагальнені дії з метою корекційного курсу 3 математики для першокурсників.

Таким чином, інструментальний компонент готовності визначено як перелік універсальних дій узагальнених методів вирішення типових професійних задач, які потребують застосування математичних знань.

Не менш важливо, на наш погляд, до структури готовності першокурсників щодо вивчення математики включити компонент, що відображає комунікативні, творчі здібності та особисті якості, необхідні для індивідуальної та командної роботи з вирішення типових професійних завдань. Цей компонент готовності назвемо особистісним.

Таким чином, спираючись на існуючі підходи щодо розуміння суті готовності до навчальної діяльності у 3ВО, враховуючи кінцеву мету математичної підготовки у ЗВО, а також взявши за основу концепцію навчання математики на основі формування узагальнених методів вирішення типових професійних задач, у структурі готовності студентів першого курсу до вивчення ма- 
тематики у ЗВО нами виділено чотири взаємопов'язаних компоненти: мотиваційно-ціннісний, змістовний, інструментальний та особистісний.

Вищезазначене надає підстави розробити методику формування готовності студентів першого курсу до вивчення математики у ЗВО, що представляє взаємозв'язок цільового, методологічного, змістовного, процесуального та результативнооцінного компонентів:

- цільовий компонент зумовлений соціальним замовленням та недостатнім рівнем математичної підготовки абітурієнтів 3ВО;

- методологічний компонент спирається на теоретичні положення наступних методологічних підходів: системнодіяльнісного, компетентнісного, контекстного та відповідні їм дидактичні принципи: співробітництва, професійної спрямованості, фундаментальності, модульності змісту математичної підготовки;

- змістовний компонент включає дисципліни освітньої програми «014 Середня освіта (Математика)»;

- процесуальний компонент включає методи, засоби, форми та етапи методики формування готовності до вивчення математики першокурсників у процесі математичної підготовки.

- результативно-оцінний компонент розроблений з урахуванням специфіки структури готовності студентів першого курсу до вивчення математики у 3ВО і містить критерії, рівні та засоби оцінювання сформованості даної готовності.

\section{Висновки}

Отже, проведений аналіз досліджуваної проблеми дозволив констатувати, що нині відсутнє загальноприйняте трактування поняття «готовність студентів першого курсу до вивчення математики у 3ВО» як результату математичної підготовки абітурієнта, який є необхідною умовою формування математичної компетентності випускників 3ВО. У зв'язку з цим, у статті на основі аналізу змісту математичної компетентності випускника ЗВО (як результату математичної підготовки у 3ВО), 3 позиції системно-діяльного, контекстного та компетентнісного підходів, уточнено суть поняття готовності до вивчення математики у ЗВО як результату підготовки до опанування узагальненими методами 
вирішення типових професійних задач, які потребують застосування математичних знань.

Таким чином, зміст структурних компонентів готовності до вивчення математики у ЗВО визначатимемо як: мотиваційноціннісний, змістовий, інструментальний, особистісний. Розроблена нами методика містить взаємозв'язок цільового, методологічного, змістовного, процесуального та результативнооцінного компонентів.

Перспективи подальших розвідок вбачаємо в реалізації розробленої методики в освітній процес студентів-математиків педагогічних університетів.

\section{Література}

1. Жерновникова О. А. Методологічні підходи як підгрунтя дидактичної підготовки майбутнього вчителя математики до проектування навчальної діяльності старшокласників. Педагогічний альманах. Херсон : КВНЗ «Херсонська академія неперервної освіти», 2016. Вип. 29. С. 123-129.

2. Жерновникова О. А., Перетяга Л. Є., Ковтун А. В., Кордубан М. В., Наливайко О. О., Наливайко Н. А. Технологія формування цифрової компетентності майбутніх учителів засобами гейміфікації. Інформаційні технологї $і$ засоби навчання. 2020. № 75(1). C. 170-185. https://doi.org/10.33407/itlt.v75i1.3036

3. Жерновникова О. А. Вибрані питання викладання математики в навчальних закладах середньої професійної та загальної освіти : навчально-методичний посібник. Харків. : Мітра, 2016.78 c.

4. Жерновникова О. А. Дидактична підготовка майбутніх учителів математики до проектування навчальної діяльності старшокласників: теоретичний та методичний аспекти : монографія. Харків : Видавець Іванченко I.C., 2015. 404 с.

5. Жерновникова О. А., Проскурня О. І. Методичні аспекти програми підвищення кваліфікації вчителів математики. Ocвіта дорослих: світові тендениії, українські реалії та перспективи : монографія / За заг. ред. акад. Н.Г. Ничкало, акад. І.Ф. Прокопенка. Київ, Харків : Інститут освіти дорослих імені І. Зязюна НАПН України, Харківський національний педагогічний університет імені Г.С. Сковороди, 2020. С. 385-389. 
6. Жерновникова О. А., Штефан Л. А., Фазан В. В. Формування готовності майбутніх учителів математики до навчального проектування [Forming future mathematics teachers' instructional design skills]. Наука і освіта: науково-практичний журнал. Одеса : ПНПУ імені К. Д. Ушинського, 2017. Вип. 10. С. 74-81. DOI: https://doi. org/10.24195/2414-4665-2017-10-9.

7. Наливайко О. O. Stop motion проекти як засіб формування цифрової компететності здобувача освіти. Наукові записки кафедри педагогіки. Харків. 2019. 1(45). С. 13-20. https://doi. org/10.26565/2074-8167-2019-45-02.

8. Пономарьова Н. О., Олефіренко Н. В., Жерновникова О. А., Масич В. В. Потенційні можливості позааудиторної роботи для інтелектуального розвитку майбутніх учителів фізико-математичного факультету Харківського національного педагогічного університету імені Г. С. Сковороди. Духовноінтелектуальне виховання $i$ навчання молоді в XXI столітті : міжнародна колективна монографія / за заг. ред. проф. В. П. Бабича, проф. Л. С. Рибалко. Харків: Вид. ВННОТ, 2019. С. 226-230.

9. Шевчук Л. Д. Неперервна професійна підготовка майбутніх учителів математики засобами IКТ: теоретичні та методичні засади : монографія. Київ : ОЛДІ-ПЛЮС, 2019. 465 с.

10. Шевчук Л. Д. Професійна підготовка майбутнього вчителя математики у процесі навчання у ВНЗ. Рідна школа. Київ, 2015. Вип. 11-12. С. 44-47.

11. Grineva V., Zhernovnykova O., Kovalenko O. European experience in training prospective teachechers. Лiдер. Еліта. Суспільство. Харків, 2018. Вип. 1. С. 91-99. doi: 10.20998/26163241.2018.1.09.

12. Ponomarova N., Gulich O., Zhernovnykova O., Olefirenko N., Masych N. Conditions of blended learning implementation in H. S. Skovoroda Kharkiv National Pedagogical University: experience of Physics and Mathematics Faculty. Second International Conference on History, Theory and Methodology of Learning (ICHTML 2021). Kryvyi Rih, Ukraine, May 12-14, 2021. P. 1-8.

13. Zolotukhina S., Bashkir O., Zhernovnykova O. Stages of Training Future Mathematics Teachers in The Field of Pedagogical Improvisation. Наука і освіта. Одеса, 2018. №4. 80-86. 
Жерновникова О.А., Простакова Ю. С.

\section{Методика формування готовності студентів-математиків до вивчення математичних дисциплін}

\section{Анотація}

У вступі статті проаналізовано сучасний стан формування готовності студентів-математиків до вивчення математичних дисциплін. Основною метою дослідження $є$ розробка та наукове обгрунтування методики формування готовності студентів-математиків до вивчення математичних дисциплін. У процесі виконання мети були застосовані теоретичні та практичні методи пошуку та обробки даних. Проведений аналіз досліджуваної проблеми дав можливість схарактеризувати суть поняття «готовність студентів-математиків до вивчення математичних дисциплін» як результату математичної підготовки абітурієнта, який $є$ необхідною умовою формування математичної компетентності випускників педагогічних університетів. У статті визначено зміст структурних компонентів готовності студентів-математиків до вивчення математичних дисциплін: мотиваційно-ціннісний (наявність мотивів та потреби у вивченні математики, усвідомлення цінності математичних знань для майбутньої професійної діяльності), змістовий (математичні знання шкільного курсу математики, необхідні для оволодіння опорними математичними знаннями узагальнених методів вирішення типових професійних задач), інструментальний (універсальні дії узагальнених методів вирішення типових професійних завдань, що потребують використання математичних знань), особистісний (комунікативні, творчі здібності та особистісні якості, необхідні для вирішення типових професійних завдань). Дидактичними принципами формування готовності $\epsilon$ : принцип співробітництва, професійної спрямованості, фундаментальності, модульності змісту математичної підготовки. Розроблено методику формування готовності студентів-математиків до вивчення математичних дисциплін, яка містить взаємозв'язок цільового, методологічного, змістовного, процесуального та результативно- 
оцінного компонентів. Перспективи подальших досліджень плануються в напрямі реалізації розробленої методики в освітній процес студентів-математиків педагогічних університетів.

Ключові слова: студенти-математики, освітній процес, математичні дисципліни, університет, готовність, формування.

\section{Жерновникова О.А., Простакова Ю. С.}

\section{Методика формирования готовности студентов-математиков к изучению математических дисциплин}

\section{Аннотация}

Во введении статьи проанализировано современное состояние формирования готовности студентов-математиков к изучению математических дисциплин.

Основная цель исследования - разработка и научное обоснование методики формирования готовности студентов-математиков к изучению математических дисциплин. В процессе выполнения целей были применены теоретические и практические методы поиска и обработки данных. Проведен анализ исследуемой проблемы охарактеризовать суть понятия «готовность студентов-математиков к изучению математических дисциплин» как результата математической подготовки абитуриента, являющегося необходимым условием формирования математической компетентности выпускников педагогических университетов. В статье определено содержание структурных компонентов готовности студентов-математиков к изучению математических дисциплин: мотивационно-ценностный (наличие мотивов и потребности в изучении математики, осознание ценности математических знаний для будущей профессиональной деятельности), содержательный (математические знания школьного курса математики, необходимые для овладения опорными) знаниями обобщенных методов решения типовых профессиональных задач), инструментальный (универсальные действия обобщенных методов решения типовых профессиональных задач), личностный (коммуникативные, творческие способности и личностные качества, необходимые для решения типовых профессиональных задач). Разработана методика формирования го- 
товности студентов-математиков к изучению математических дисциплин, содержащая взаимосвязь целевого, методологического, содержательного, процессуального и результативно-оценочного компонентов. Перспективы дальнейших исследований планируются по реализации разработанной методики в образовательный процесс студентов-математиков педагогических университетов.

Ключевые слова: студенты-математики, образовательный процесс, математические дисциплины, университет, готовность, формирование. 